\title{
Maternal Hypoxia as a Model for Intrauterine Growth Retardation: Effects on Insulin-Like Growth Factors and Their Binding Proteins
}

\author{
PAIVI J. TAPANAINEN, PETER BANG, KRISTIN WILSON, TERRY G. UNTERMAN, \\ HENDRIK J. VREMAN, AND RON G. ROSENFELD \\ Department of Pediatrics, Stanford University, Stanford, California 94305 /P.J.T., P.B., K.W., \\ H.J.V., R.G.R.]; Department of Pediatrics, University of Oulu, Finland [P.J.T.]; and \\ Department of Medicine, University of Illinois College of Medicine and VA West Side Medical \\ Center, Chicago, Illinois 60612 /T.G.U.l
}

\section{ABSTRACT}

Evidence suggests that IGF and their binding proteins play a role in fetal growth, but more knowledge concerning their regulation is essential. We examined the expression of IGF and their binding proteins in experimental intrauterine growth-retarded (IUGR) rat fetuses of hypoxic dams (13$14 \%$ oxygen, $d 14-21$ of gestation). The mean body weight of the fetuses (d 21 of gestation, $n=72$ ) of the six hypoxic dams was $24 \%$ lower $(p<0.0001)$ than the mean weight of the fetuses of six control dams $(n=82)$. Wet liver weights demonstrated a $20 \%$ decrease $(p<0.0001)$ and placentas a $10 \%$ decrease $(p<0.01)$ compared with control fetuses. The mean serum concentrations of immunoreactive IGF-I in both groups were low but did not differ significantly. The mean serum concentrations of immunoreactive IGF-II, however, were higher in IUGR fetuses. As assessed by Northern blot analysis, there was a 4-fold increase in insulin-like growth factor binding protein-1 (IGFBP-1) mRNA expression in the livers of the IUGR fetuses compared with controls. IGFBP-2 mRNA expression was 6-fold increased

Evidence suggests that IGF and their binding proteins play a role in the regulation of fetal growth and development, but more knowledge of their interaction is essential. In the rat, gene expression for IGF-II is high in many fetal tissues, and high levels of IGF-II are also found in fetal serum (1). The finding that fetal IGF-II concentrations are elevated, rather than reduced, in growth retardation suggests that IGF-II has a function in assisting in the metabolic adaptation of the fetus to the growth-

Received June 1, 1993; accepted February 23, 1994.

Correspondence and reprint requests: Paivi J. Tapanainen, M.D., Department of Pediatrics, University of Oulu, Kajaanintie. FIN-90220 Oulu. Finland.

Supported in part by grant DK 360154 from the NIH (R.G.R.); by the ESPE Research Fellowship, Paulo Foundation, Helsinki, Finland and the Alma och K.A. Snellman Foundation, Oulu, Finland (P.J.T.); and by the Swedish Medical Research Council and Novo-Nordisk (Nordisk grant for the study of growth) (P.B.). in IUGR fetal livers. No difference was found in IGFBP-4 mRNA. An increase in IGFBP-1, -2 , and -4 concentrations could be seen by Western ligand blotting in the serum of growth-retarded fetuses compared with control fetuses. This finding was verified by immunoprecipitation with specific antibodies, which demonstrated increases in IGFBP-1 and IGFBP-2. Our results validate the use of maternal hypoxia as an experimental model of intrauterine growth retardation and indicate that increased IGFBP-1 and -2 expression may be of importance in the etiology of fetal growth retardation caused by maternal hypoxia. (Pediatr Res 36: 152-158, 1994)
Abbreviations
IGFBP, insulin-like growth factor binding protein IUGR, intrauterine growth retardation or intrauterine growth retarded ir, immunoreactive rIGFBP, rat insulin-like growth factor binding protein

retarded state (2). The gene for IGF-I is also expressed in a variety of fetal tissues, but at lower levels than the gene for IGF-II (3). IUGR in different animal models has been shown to be associated with decreased IGF-I concentrations (4-7), suggesting that fetal serum IGF-I could be a valuable marker for intrauterine substrate deprivation. On the other hand, there are studies that fail to demonstrate any difference in IGF-I levels between short-term hypoxic and normal ovine fetuses (8). The actions of IGF are modulated by specific IGFBP. To date, six distinct IGFBP have been identified and their cDNA cloned and sequenced (9-11). In most experimental situations, IGFBP have been found to decrease IGF actions, presumably by binding IGF $(9-11)$. Such an inhibitory role is suggested by the increase in IGFBP-1 expression found in experimentally induced fetal growth retardation $(5,12$, 13). Controversy still exists concerning the expression of 
the IGFBP-2 gene in retarded fetal growth. It has been shown to be increased (13) and unchanged $(5,12)$. Hypoxia for $24 \mathrm{~h}$ induced by the reduction of maternal uterine blood flow was recently shown to decrease the expression of IGBP-2 in ovine fetuses (8). The etiology of IUGR can be either genetic or acquired. Mechanical late constraint has been emphasized as perhaps the most common cause of IUGR. Clinically, most fetal growth retardation states are associated with inadequate supply of both oxygen and nutrients to the fetus. Experimental models of growth retardation have generally used either interference with placental function (2) or uterine blood flow $(6,12,13)$ or limitation of maternal energy and protein intake to restrict fetal growth $(5,7,14)$. We have used maternal hypoxia as a model for IUGR and have studied its effect on IGF and their binding proteins to clarify their role in retarded fetal growth.

\section{METHODS}

Animals and study design. Timed pregnant SpragueDawley rats $(n=12)$ were obtained from Simonsen Breeding Colonies (Gilroy, CA). IUGR was induced by exposure of the dams $(n=6)$ to $13-14 \%$ oxygen between d 14 and 21 of gestation, as previously described (15). Special environmental chambers were designed for this purpose. At lower oxygen saturations $(9.5-11 \%)$, increased fetal wastage was observed, with a reduction in litter size from 13 to eight. Six additional dams served as controls and were exposed to $21 \%$ oxygen in similar environmental chambers. The rats were maintained with standard lighting (lights on 0500-1900 h daily) and temperature $\left(26^{\circ} \mathrm{C}\right)$ under standard vivarium conditions approved by the American Association for Accreditation of Laboratory Animal Care. Tap water and food were available ad libitum. There was no significant difference in food consumption between the study groups (data not shown).

On d 21, a cesarean section was performed under ketamine and xylazine anesthesia. Fetuses were removed from the uterus, weighed, and killed by decapitation. Blood was collected from the cervical stumps, allowed to clot at $4^{\circ} \mathrm{C}$ for $30 \mathrm{~min}$, and centrifuged at $10000 \mathrm{rpm}$ for $15 \mathrm{~min}$ to separate serum. The serum samples were stored at $-20^{\circ} \mathrm{C}$ until analyzed. Livers were quickly removed, weighed, frozen in liquid nitrogen within $5 \mathrm{~min}$ of decapitation, and subsequently stored at $-70^{\circ} \mathrm{C}$. These studies were approved by The Ethical Animal Committee of Stanford University School of Medicine.

IGF peptides and IGFBP antibodies. Pure biosynthetic IGF-I was purchased from Bachem (Philadelphia, PA). Recombinant IGF-II was generously provided by Dr. Michele Smith (Lilly Research Laboratories, Indianapolis, IN). The peptides were iodinated by a modification of the chloramine-T technique to specific activities of 150 $250 \mu \mathrm{Ci} / \mu \mathrm{g}$. Rabbit polyclonal antiserum aHEC, raised against IGF-II affinity-purified medium from a human endometrial carcinoma cell line, specifically recognizes rat IGFBP-2 and does not cross-react with rIGFBP-3, as previously described (16). Antiserum against rat IGFBP-1 was prepared as previously described (17).

IGF-I and IGF-II RIA. Serum samples were chromatographed in $0.25 \mathrm{M}$ formic acid on a $0.9 \times 100$-cm column of Sephadex G-50 (Pharmacia Fine Chemicals, Piscataway, NJ). The fractions eluting between 50 and $67 \mathrm{~mL}$, which contain $90 \%$ of the IGF activity and no demonstrable IGFBP, were collected in glass tubes containing 1.0 $\mathrm{mL}$ of $1 \% \mathrm{BSA}$ and were subsequently frozen and lyophilized. Serum IGF-I was measured by RIA, using [ ${ }^{125}$ I]IGF-I as radioligand and a polyclonal anti-IGF-I antibody. This antiserum (UBK487) was a generous gift from the hormone distribution program of the National Institute of Diabetes and Digestive and Kidney Diseases and was originally provided by Drs. J. J. Van Wyk and L. E. Underwood (University of North Carolina). Serum IGF-II was measured by RIA using [ [ ${ }^{125}$ I]IGF-II as a radioligand and an MAb against rat IGF-II (Amano Enzyme Co., Inc., Troy, VA). The detection limits of the assays for IGF-I and -II were 0.1 and $0.5 \mathrm{ng} / \mathrm{mL}$, respectively, and the interassay coefficients of variation were 13.3 and $16.3 \%$, respectively.

Western ligand blotting. Analysis of IGFBP in fetal serum by Western ligand blotting was performed as originally described by Hossenlopp et al. (18) with minor modifications. Briefly, SDS-PAGE was performed according to the methods of Laemmli (19) in a $12 \%$ polyacrylamide gel with a $4 \%$ stacking gel. Twenty $\mu \mathrm{L}$ of $1: 10$ diluted serum were applied per lane, and prestained molecular weight markers (BRL, Bethesda, MD) were run in parallel lanes. After electrophoresis, the IGFBP were transferred to nitrocellulose $(0.45-\mu \mathrm{m}$ pore size $)$ in a Hoeffer Semi-dry Transphor unit (San Francisco, CA) at $200 \mathrm{~mA}$. The filters were blocked with $1 \% \mathrm{BSA}$, as described earlier (18), before an overnight incubation at $4^{\circ} \mathrm{C}$ with approximately $1.5 \times 10^{\circ} \mathrm{cpm}$ of a mixture of equal amounts of $\left[{ }^{125}\right.$ I]IGF-I and $\left[{ }^{125}\right.$ I]IGF-II. Thereafter, filters were washed with $0.1 \%$ Tween 20 in Tris-buffered saline for $20 \mathrm{~min}$ and $120 \mathrm{~min}$, air dried, and exposed to Kodak X-Omat AR film (Eastman Kodak, Rochester, $\mathrm{NY}$ ) for $4 \mathrm{~d}$ at $-70^{\circ} \mathrm{C}$.

Immunoprecipitation. Serum IGFBP were immunoprecipitated using specific IGFBP antibodies. Five $\mu \mathrm{L}$ of fetal serum and $5 \mu \mathrm{L}$ of the undiluted antiserum (a-HEC or a-IGFBP-1) were mixed with $40 \mu \mathrm{L}$ of $N$-2-hydroxyethylpiperazine- $N^{\prime}$-2-ethanesulfonic acid and incubated overnight at $4^{\circ} \mathrm{C}$. The IGFBP-antibody complexes were precipitated by addition of $50 \mu \mathrm{L}$ of Pansorbin and incubation for $4 \mathrm{~h}$ at $20^{\circ} \mathrm{C}$. The pellets were washed three times with $N$-2-hydroxyethylpiperazine- $N^{\prime}$-2-ethanesulfonic acid and, after the addition of nonreducing SDS sample buffer, the pellets were boiled for $5 \mathrm{~min}$. The supernatants were processed for Western ligand blotting as described above.

RNA isolation and Northern blot analysis. Total cellular RNA was isolated from liver tissues using the modified guanidine thiocyanate cesium chloride method as previ- 
ously described (20). Total RNA $(20 \mu \mathrm{g})$ was size fractionated in a $1.2 \%$ agarose-formaldehyde gel, stained with ethidium bromide $(1 \mu \mathrm{g} / \mathrm{mL}$ for $5 \mathrm{~min})$, and transferred to nitrocellulose $(0.45-\mu \mathrm{m}$ pore size $)$. An RNA ladder (BRL, Gaithersburg, MD) was run in parallel with the samples to allow sizing of the mRNA. The nitrocellulose filters were photographed in UV light, and the ethidium bromide-stained 18 S RNA bands were used to reflect the total amount of RNA loaded in each lane. The filters were then hybridized with rat cDNA for IGFBP-1 and IGFBP-2 and a human CDNA for IGFBP-4, according to the method of Wahl et al. (21), and exposed to Kodak X-Omat AR film with an intensifying screen at $-70^{\circ} \mathrm{C}$ for $4-14 \mathrm{~d}$.

The cDNA probe for rat IGFBP-1 was a 350-bp HindIII-EcoRI insert of a fragment isolated from a rat decidual cDNA library (22). The probe for rat IGFBP-2 was a 1295-bp EcoRI restriction fragment of a 1500-bp cDNA isolated from a rat liver cDNA library and contained the entire coding region (23). The probe for human IGFBP-4 was a 440-bp SmaI restriction fragment of the 1.2-kb cDNA isolated from a human osteosarcoma cell gene library (24). These cDNA were generously provided by Drs. L. Murphy, J. Schwander (Basel, Switzerland) and S. Mohan (Loma Linda, CA), respectively. The probes were labeled with $\left[{ }^{32} \mathrm{P}\right] \mathrm{dCTP}$ (Amersham Co., Arlington Heights, IL) by random priming, using a commercial kit (Pharmacia, Uppsala, Sweden).

Quantification of autoradiograms. The relative levels of IGFBP and mRNA on autoradiograms of Western ligand blots and Northern blots, respectively, were quantified by laser densitometry (UltraScan XL, LKB, Bromma, Sweden). The relative densities of the bands were expressed as arbitrary absorbance units per $\mathrm{mm}$.

Calculations and statistical analysis. Western ligand blotting of plasma samples and Northern analysis of total RNA samples from livers of control and IUGR fetuses were all performed a minimum of three times. Statistical significance between the two groups of animals was calculated using the $t$ test. The results are expressed as mean $\pm \mathrm{SD}$.

\section{RESULTS}

Somatic growth. Maternal hypoxia resulted in IUGR, which was reflected by a significant decrease in fetal weight. The mean body weight of the fetuses $(n=72)$ from the hypoxic dams $(n=6)$ was $24 \%$ lower $(p<$ $0.0001)$ than the mean weight of the fetuses $(n=82)$ of the control dams $(n=6)$. Wet liver weights of hypoxic fetuses demonstrated a 20\% decrease $(p<0.001)$ and placentas a $10 \%$ decrease $(p<0.01)$ compared with control fetuses (Fig. 1). The mean litter size did not differ significantly between the groups $(12 \pm 1.1$ and $14 \pm 0.8$, respectively).

Serum IGF. The mean serum concentration of ir-IGF-I, determined from the pooled sera of all the fetuses of one dam, was low in both groups $(54 \pm 7 \mu \mathrm{g} / \mathrm{L}$ in IUGR

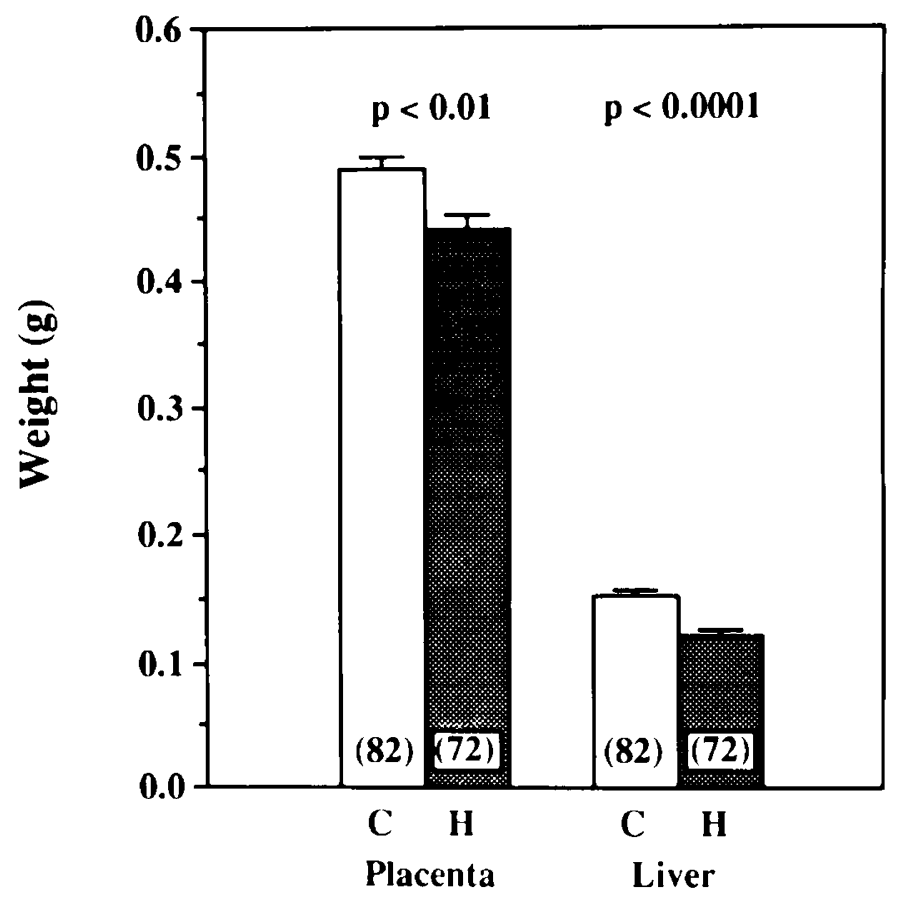

Figure 1. Liver and placenta weights of the fetuses of the control $(C, n$ $=6)$ and hypoxic $(H, n=6)$ dams on d 21 of gestation. Values are expressed as the mean \pm SD. There were 82 fetuses in the control group and 72 fetuses in the hypoxic group.

fetuses and $59 \pm 9 \mu \mathrm{g} / \mathrm{L}$ in control fetuses), but there was no significant difference between the groups. The mean concentrations of ir-IGF-II were high: $418 \pm 33 \mu \mathrm{g} / \mathrm{L}$ in the IUGR fetuses, and $297 \pm 31 \mu \mathrm{g} / \mathrm{L}$ in the control fetuses. The IGF-II values thus tended to be higher in the IUGR group, with the difference just reaching significance $(p=0.05)$.

Serum IGFBP. Figure $2 A$ shows the Western ligand blot of IGFBP of IUGR and control fetuses of each dam. Each lane represents the pooled sera of all the fetuses of one dam. The comparison of relative quantities of different IGFBP, as determined by densitometry, is shown in Figure $2 B$. Western ligand blotting of the sera showed a very weak 38- to 44-kD band, representing rIGFBP-3; a distinct $28-\mathrm{kD}$ band consisting of rIGFBP-1 and rIGFBP-2 (see below); and a 24-kD band, tentatively identified as rIGFBP-4. Compared with control fetuses, the $28-\mathrm{kD}$ band was 1.75 -fold more intense in the IUGR fetuses $(p<0.001)$. The $24-\mathrm{kD}$ band was also more intense (2.5-fold) in the IUGR fetuses compared with controls $(p<0.001)$. The $28-\mathrm{kD}$ band was shown to consist of both IGFBP-1 and IGFBP-2 by immunoprecipitation with specific antisera against IGFBP-1 or IGFBP-2 (Fig. 3). It was not possible, however, to completely resolve the $28-\mathrm{kD}$ band, although immunoprecipitation studies suggest that both IGFBP-1 and IGFBP-2 are increased in hypoxic fetuses. This conclusion is supported by mRNA studies (see below).

Tissue IGFBP mRNA levels. The effect of maternal hypoxia on IGFBP-1, IGFBP-2, and IGFBP-4 mRNA levels in hypoxic and control fetuses is shown in Figure 4. 
A.

$\mathbf{H}$

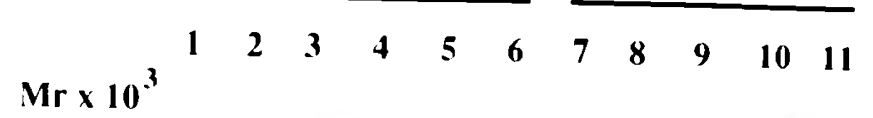

$\operatorname{Mr} \times 10^{3}$

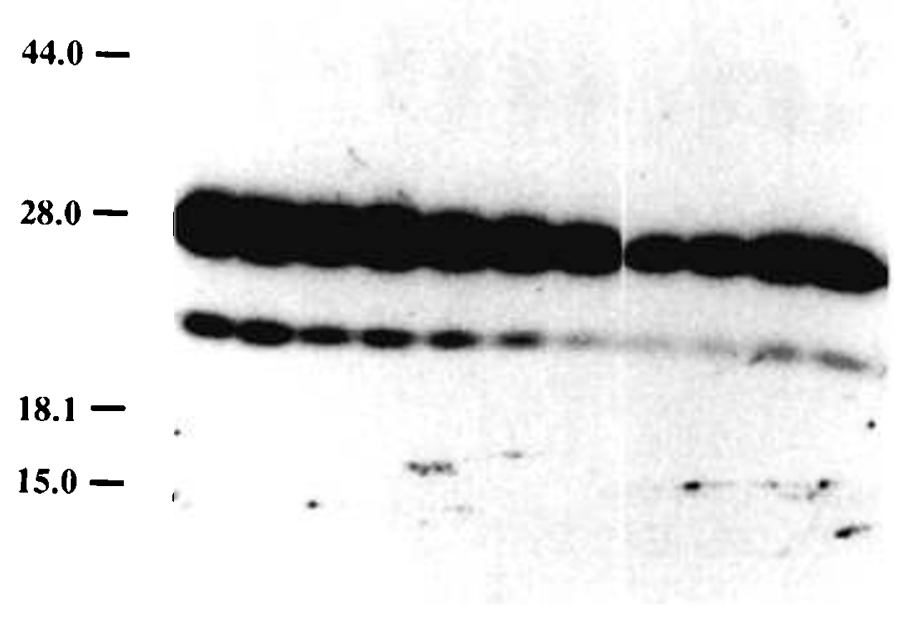

B.

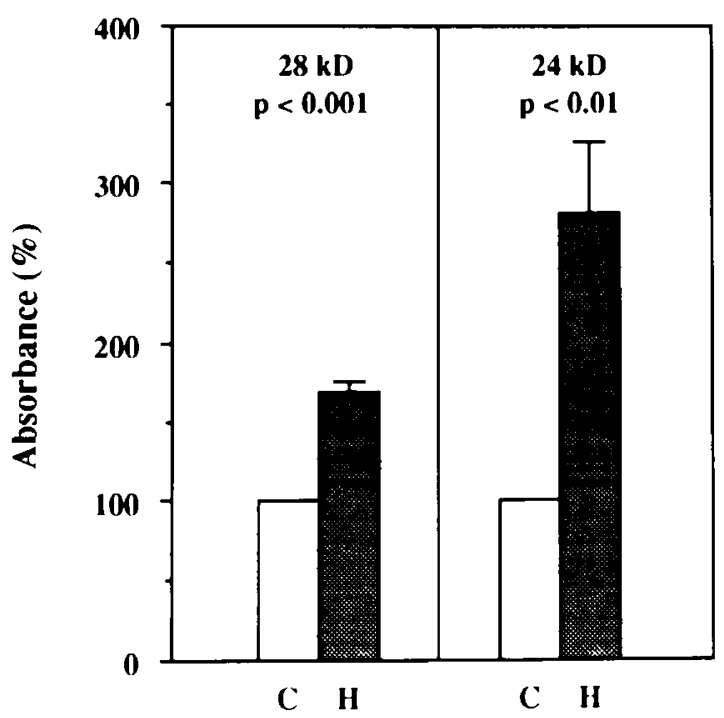

Figure 2. $A$, Western ligand blot of IGFBP in the sera $(5 \mu \mathrm{L})$ of hypoxic $(H$, lanes $1-6)$ and control $(C$, lanes $7-11)$ fetuses of each dam. Each lane represents pooled sera from all the fetuses from one dam. The 28-kD band contains both IGFBP-1 and IGFBP-2 (see Fig. 4). The molecular weights $(M r)$ of the IGFBP are indicated on the left. $B$, Respective densitometric data are shown. Mean and SD for each group are given.

IGFBP-1 mRNA in the fetal liver consisted predominantly of a major species of $1.8 \mathrm{~kb}$; one minor species of $4.0 \mathrm{~kb}$ was also observed. IGFBP-1 mRNA levels were increased approximately 4-fold in the IUGR fetuses compared with fetuses from control dams. IGFBP- 2 mRNA in fetal livers consisted of one major band of $1.6 \mathrm{~kb}$. Maternal hypoxia was also found to have an inducing

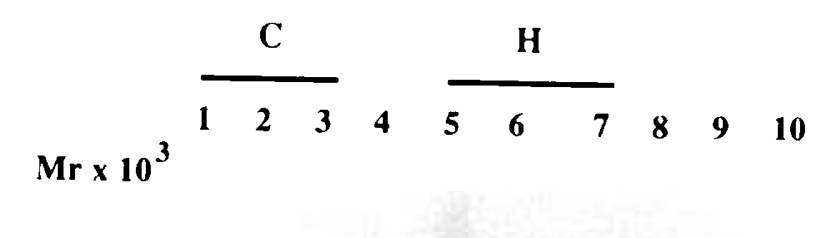

$28.0-$

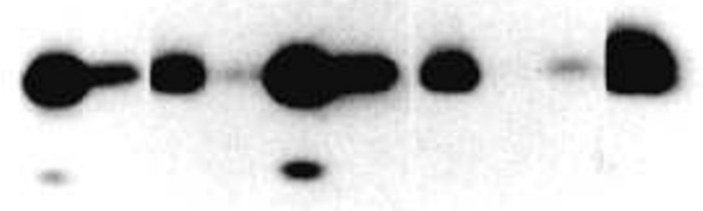

$18.1-$

Figure 3. Immunoprecipitation and ligand blotting of IGFBP in fetal serum. Lanes $1-4$ represent controls $(C)$, and lanes $5-8$ represent hypoxic $(H)$ fetuses. Lanes $I$ and 5 represent Western ligand blots of pooled sera of the fetuses. Lanes 2 and 6 represent ligand biots of pooled sera immunoprecipitated with antibody against IGFBP-1; lanes 3 and 7 represent ligand blots of pooled sera immunoprecipitated with antibody against IGFBP-2: lanes 4 and 8 represent ligand blots of nonimmune rabbit serum. Lane 9 represents an immunoprecipitated ligand blot of fetal rat serum as a positive control for IGFBP-2, and lane 10 represents an immunoprecipitated ligand blot of dexamethasonetreated H4IIE cell-conditioned medium as a positive control for IGFBP-1. The molecular weights $(\mathrm{Mr})$ of the IGFBP are indicated on the left.

effect on the level of fetal liver IGFBP-2 mRNA, with levels approximately 6 -fold higher in the IUGR fetuses. IGFBP-4 mRNA consisted of one $1.75-\mathrm{kb}$ band. In contrast to IGFBP-1 and IGFBP-2, no increase was found in IGFBP-4 mRNA levels between the groups.

\section{DISCUSSION}

We used maternal hypoxia as an experimental model for IUGR and observed $24 \%$ growth retardation in 21-dold fetuses, without significant fetal wastage. This is in agreement with other studies in which maternal hypoxia has been used to retard fetal growth and in which the percent retardation of fetal weight varied between 13 and $36 \%$, depending on the oxygen concentration and length of exposure to hypoxia $(25,26)$. The observed growth retardation was comparable to that observed with other experimental rat IUGR models, such as ligation of the uterine artery $(6,12,13,17)$, maternal fasting $(5,7,14)$, and maternal dexamethasone treatment (27). The mechanism by which maternal hypoxia causes IUGR differs from that of maternal fasting. No difference was found in the maternal food intake in our model, so the role of nutrient availability plays a minor role in the hypoxia model. However, maternal hypoxia has some similarities with the ligation of uterine artery model, in which there is graded reduction in uterine blood flow. Both models lead to centralization of blood flow in favor of the brain, heart, and adrenals at the expense of almost all peripheral organs. This response has been shown to be qualitatively similar but quantitatively different between the models (28). Although all of the experimental models described 
A.

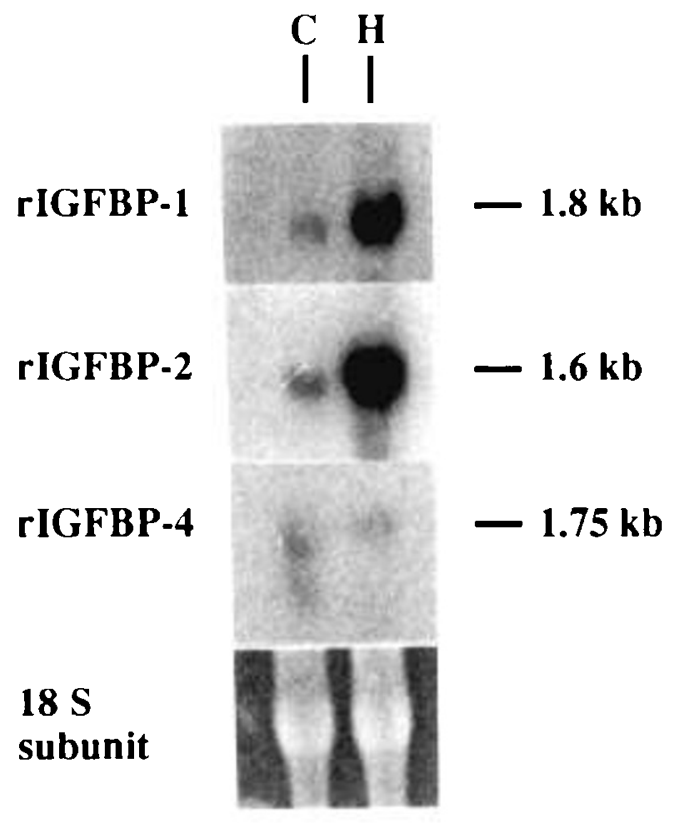

B.

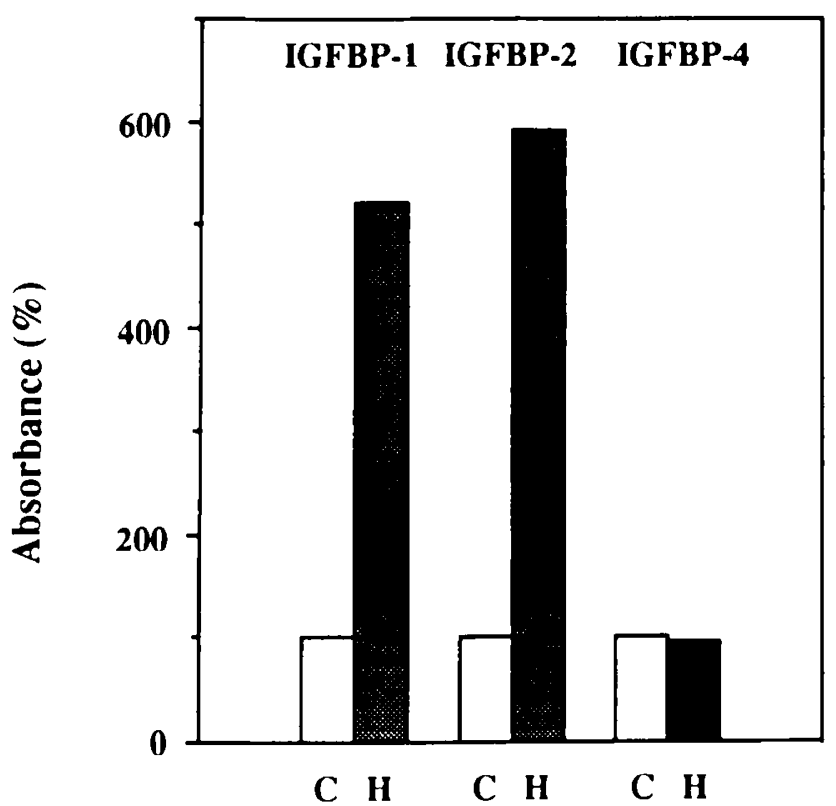

Figure 4. $A$, Autoradiograms of representative Northern hybridization analyses of mRNA from pooled livers of control $(C)$ and hypoxic $(H)$ fetuses. Each lane represents $20 \mu \mathrm{g}$ of mRNA extracted from tissues and hybridized with specific ${ }^{32}$ P-labeled rIGFBP-1 (14-d exposure), rIGFBP-2 (14-d exposure), or hIGFBP-4 (4-d exposure) cDNA probes. The size of each hybridization band $(k b)$ is shown to the right of the autoradiograms. $B$, Respective densitometric data are shown.

above have produced useful information, none of them are totally satisfactory. Surgical approaches for determining hormonal regulation of fetal growth are invasive and technically difficult because of the small size of most laboratory animals. Furthermore, it has been shown that any type of surgical invasion of the uterus results in nonspecific growth inhibition of rat fetuses (29). Our model has some similarities with the situation observed in humans living at high altitude, where the mean birth weight of babies has been shown to be lower than the weight of those born at sea level, as well as with IUGR fetuses of rhesus isoimmunized mothers $(30,31)$, especially because the hypoxia model does not include any surgical intervention and results in significant growth retardation without invasive methods. Although it results in IUGR, it may not be the best model for evaluation of placental insufficiency as a cause of fetal growth retardation. Although the mean weight of the placentas was reduced by $10 \%$, the etiology of fetal growth failure in hypoxia may be different from that observed with primary placental inadequacy.

We could not detect any significant difference in irIGF-I levels between hypoxic and control fetuses, which suggests that total circulating IGF-I levels do not explain the growth retardation seen in this model. Our results are in contrast to those of maternal malnutrition studies, in which circulating IGF-I levels were decreased and speculated to cause IUGR $(5,7,14)$. On the other hand, restriction of maternal blood flow for $24 \mathrm{~h}$ did not influence circulating IGF-I levels in ovine fetuses, suggesting that hypoxia probably causes IUGR by other mechanisms, which is in agreement with our findings (8). Although the biologic role of IGF-I in postnatal growth is well established, there is still some controversy concerning its role as a fetal growth factor in the rat, despite the fact that many fetal rat tissues synthesize IGF-I mRNA (32). In contrast, evidence strongly suggests that IGF-II is an important regulator of growth during fetal life (33, 34) and may even have a function in assisting in the metabolic adaptation of the fetus to the growth-retarded state (2). In the present study, the levels of ir-IGF-II were higher in IUGR fetuses, which is in agreement with the results of the study of Jones et al. (2). The concentrations of IGF-II in serum are known to decrease rapidly to very low levels after birth (35), as does the level of expression of the IGF-II gene. It is possible that the hypoxic fetuses are developmentally delayed compared with control fetuses, and therefore they retain higher IGF-II levels. It can also be speculated that increased levels of IGFBP-1 and -2 provide an increased IGF-II binding capacity. However, inasmuch as tissue IGF-II mRNA levels were not determined, this cannot be proved by the present study. In the growth-retarded fetuses, we demonstrated an increase in the $28-\mathrm{kD}$ IGFBP, which, by immunoprecipitation, clearly consisted of both IGFBP-1 and -2 . Northern blot studies indicated increased mRNA for both IGFBP, and it is likely that Western ligand blot data reflect a rise in protein level as well. The 1.75-fold increase in serum IGFBP-1 and -2 levels, supported by immunoprecipitation with specific antibodies, was accompanied by a 4-fold increase in liver IGFBP-1 mRNA and a 6-fold increase in IGFBP-2 mRNA, suggesting that 
Table 1. Induction of IUGR in rats and the effects of IUGR on serum and liver IGF and IGFBP*

\begin{tabular}{|c|c|c|c|c|c|c|c|c|c|c|}
\hline \multirow[b]{2}{*}{ Authors } & \multirow[b]{2}{*}{ IUGR model } & \multirow{2}{*}{$\begin{array}{c}\text { IUGR } \\
\left(c^{\prime}\right)\end{array}$} & \multicolumn{2}{|c|}{ Serum } & \multicolumn{2}{|c|}{ mRNA } & \multicolumn{2}{|c|}{ Serum } & \multicolumn{2}{|c|}{ mRNA } \\
\hline & & & ir-IGF-I & ir-IGF-II & IGF-I & IGF-II & BPI & BP2 & BP1 & $\mathrm{BP} 2$ \\
\hline Vileisis and D’Ercole, $1986(6)$ & Uterine artery ligation & 28.6 & - & ND & ND & ND & ND & ND & ND & ND \\
\hline Unterman et al., $1990(12), 1993$ (17) & Uterine artery ligation & 16.3 & - & $+1-$ & ND & ND & + & $+1-$ & + & $+1-$ \\
\hline Davenport et al., $1990(14)$ & Maternal fasting & 24.5 & - & $+1-$ & $+1-$ & $+1-$ & ND & ND & ND & ND \\
\hline Straus et al., 1991 (5) & Maternal fasting & $27-32$ & - & - & - & $+1-$ & ND & ND & + & $+1-$ \\
\hline Bernstein et al., 1991 (7) & Maternal fasting & 25 & - & ND & ND & ND & ND & ND & ND & ND \\
\hline Price et al., 1992 (27) & Dexamethasone & 32 & ND & ND & $+1-$ & + & + & $+1-$ & + & + \\
\hline Price et al., 1992 (13) & Uterine artery ligation & 28.6 & ND & ND & ND & ND & + & $+1-$ & + & $+1-$ \\
\hline Tapanainen et al. (present study) & Maternal hypoxia & 24 & $+1-$ & + & ND & ND & + & + & + & + \\
\hline
\end{tabular}

+ , Increased; - , decreased; +/-, unchanged; ND, no data available.

both IGFBP-1 and IGFBP-2 are associated with retarded fetal growth. It has been previously shown that both IGFBP-1 and - 2 mRNA are expressed at high levels in liver of 21-d gestation rats (36). It has been speculated that IGFBP-1 is involved in the regulation of fetal growth, based on the fact that IGFBP-1 levels have been increased in some experimental IUGR models in the rat $(5$, $12,13,17)$. There is also evidence in human fetuses concerning the importance of IGFBP-1 in the fetal growth-retarded state. IGFBP-1 levels, as determined by RIA in umbilical cord serum, have been shown to be higher in small-for-gestational-age babies compared with average-for-gestational-age infants (37-39). In contrast, the data concerning changes in IGFBP- 2 in growthretarded states are conflicting. Increased (13) and unchanged $(5,12)$ levels have been reported, depending on the experimental model used. These different results may reflect the different models of IUGR used or the lack of specific antibodies to detect individual IGFBP. It is therefore of note that in our model of IUGR changes in serum IGFBP levels were reflected by parallel changes in mRNA (Table 1).

Insulin is proposed to be an important regulator of IGFBP-1, and there is generally an inverse relationship between the two $(40-42)$. IUGR after bilateral uterine artery ligation results in increased levels of both circulating IGFBP-1 and hepatic IGFBP-1 mRNA but a decrease in fetal insulin and glucose $(12,17)$. The mechanism by which maternal hypoxia causes increased IGFBP-1 expression may also be related to hypoinsulinemia. We were not able to measure serum insulin levels because of the limited quantities of serum obtained from these fetuses, but decreased serum insulin is well described in fetal growth failure. Increased IGFBP-1 can potentially inhibit growth by binding IGF in the circulation and thereby limiting the availability of IGF to target tissues $(12,13)$. Insulin has also been suggested to be a negative regulator of hepatic IGFBP-2 levels, suggesting a physiologically important regulatory link between the two (43). Possible hypoinsulinemia could be one explanation for increased serum IGFBP-2 and IGFBP-2 mRNA. It is also possible that other hormonal changes affect IGFBP-2 levels in our model of IUGR. On the other hand, there are studies $(8,12)$ that suggest that IGFBP-1 and IGFBP-2 are differentially regulated in utero. Our results, how- ever, indicate that IGFBP-1 and IGFBP-2 are similarly regulated in the maternal hypoxia model of fetal growth failure. Although there is now considerable evidence that IGF and IGFBP play a role in the control of fetal growth, the precise mechanism by which fetal growth is regulated is still uncertain. Whether the increases in IGFBP-1 and IGFBP-2 represent the process or the result of IUGR produced by maternal hypoxia remains to be investigated. It is possible that when the relative amounts of IGFBP-1 and IGFBP-2 in the fetus increase, the net binding capacity of fetal serum for IGF peptides also rises. This may be of particular importance in the fetal rat, where serum levels of IGFBP-3 are low (44). The rise in serum IGFBP may restrict the availability of IGF peptides to fetal tissues and thereby reduce fetal growth. We conclude that our results validate the use of maternal hypoxia as an experimental model of IUGR and indicate that increased IGFBP-1 and-2 expression may be of importance in the etiology of fetal growth retardation.

\section{REFERENCES}

1. Daughaday WH, Rotwein P 1989 Insulin-like growth factors $\mathbf{I}$ and II. Peptide messenger ribonucleic acid and gene structures, serum and tissue concentrations. Endocr Rev 10:68-91

2. Jones CT, Gu W, Harding JB. Price DA, Parer JT 1988 Studies on the growth of the fetal sheep. Effects of surgical reduction in placental size, or experimental manipulation of uterine blood flow on plasma sulphation promoting activity and on the concentration of insulin-like growth factors I and II. J Dev Physiol 10:179-181

3. D'Ercole AJ 1987 Somatomedin/insulin-like growth factors and fetal growth. J Dev Physiol 9:481-495

4. Basset NS, Oliver MH, Breier BH. Gluckman PD 1990 The effect of starvation on fetal IGF-I. Pediatr Res 27:4()1-4(1)4

5. Straus DS, Ooi GT, Orlowski CC. Rechler MM 1991 Expression of the genes for insulin-like growth factor-1 (IGF-1). IGF-II, and IGF-binding proteins-1 and -2 in fetal rat under conditions of intra-uterine growth retardation caused by maternal fasting. Endocrinology 128:518-525

6. Vileisis RA. D'Ercole AJ 1986 Tissue and serum concentrations of somatomedin-C/insulin-like growth factor $I$ in fetal rats made growth retarded by uterine artery ligation. Pediatr Res 20:126-130

7. Bernstein IM. DeSouza MM, Copeland KC 1991 Insulin-like growth factor I in substrate-deprived, growth-retarded fetal rats. Pediatr Res 30:154-157

8. McLellan KC, Hooper SB, Bocking AD, Delhanty PJD, Phillips ID, Hill DJ, Han VKM 1992 Prolonged hypoxia induced by the retardation of maternal uterine blood flow alters insulin-like growth factor-binding protein-1 (IGFBP-1) and IGFBP-2 gene expression in the ovine fetus. Endocrinology $131: 1619-1628$

9. Rosenfeld RG, Lamson G, Pham H, Oh Y, Conover C, De Ieon DD, Donovan SM. Ocrant I, Giudice L 1990) Insulin-like growth factor-binding proteins. Rec Prog Horm Res 46:99-163

10. Lamson G, Giudice LC, Rosenfeld RG 1991 Insulin-like growth factor binding proteins: structural and molecular rejationships. Growth Factors $5: 19-28$

11. Clemmons DR 1991 Insulin-like growth factor binding proteins. In: LeRoith D (ed) Insulin-Like Growth Factors. CRC Press, Boston, pp 151-180)

12. Unterman T, Lascon R, Gotway MB, Oehler D, Gounis A, Simmons RA, Ogata ES 19() Circulating levels of insulin-like growth factor binding pro- 
tein-1 (IGFBP-1) and hepatic mRNA are increased in the small for gestational age (SGA) fetal rat. Endocrinology 127:2035-2037

13. Price WA, Rong L, Stiles AD, D'Ercole AJ 1992 Changes in IGF-I and -II, IGF binding protein, and IGF receptor transcript abundance after uterine artery ligation. Endocrinology 32:291-295

14. Davenport ML, D'Ercole AJ, Underwood LE 1990 Effect of maternal fasting on fetal growth, serum insulin-like growth factors (IGFs), and tissue lGF messenger ribonucleic acids. Endocrinology 126:2062-2067

15. Van Geijn HP. Kaylor WM. Nicola KR. Zuspan FP 1980 Induction of severe intrauterine growth retardation in the Sprague-Dawley rat. Am J Obstet Gynecol 137:43-47

16. Lamson G, Pham H, Oh Y, Ocrant I, DeLeon D, Donovan S, Schwander J, Rosenfeld RG 1989 Expression of the $31 \mathrm{kd}$ (HBP-31) and $30 \mathrm{kd}$ (RBP-30) IGF binding proteins in human and rat tissues. Endocrinology 123:11(0)-1102

17. Unterman TG, Simmons RA, Glick RP, Ogata ES 1993 Circulating levels of insulin, insulin-like growth factor-I (IGF-I), IGF-Il, and IGF-binding proteins in the small for gestational age rat. Endocrinology 132:327-336

18. Hossenlopp P, Seurin D. Segovia-Quinson B. Hardouin S, Binoux M 1986 Analysis of serum insulin-like growth factor binding proteins using Western ligand blotting: use of the method for titration of the binding proteins and competitive binding studies. Anal Biochem 154:138-143

19. Laemmli V 1970 Cleavage of structural proteins during the assembly of the head of bacteriophage T4. Nature 227:680-685

20. Chomczynski P, Sacchi N 1987 Single-step method of RNA isolation by acid guanidinium thiocyanate-phenol-chloroform extraction. Anal Biochem 162:156-159

21. Wahl GM, Stern M, Stark GR 1979 Efficient transfer of large DNA fragments from agarose gels to diazobenzyloxymethol-paper and rapid hybridization using dextran sulfate. Proc Natl Acad Sci USA 76:3683-3687

22. Murphy LJ, Seneviratne C, Ballejo G, Croze F, Kennedy TG 1990 Identification of characterization of a rat decidual insulin-like growth factor-binding protein complementary DNA. Mol Endocrinol 4:329-3.36

23. Margot JB, Binkert C, Mary JL, Landwetir J, Heinrich G, Schwander J 1989 A low molecular weight insulin-like growth factor binding protein from rat: cDNA cloning and tissue distribution of its messenger RNA. Mol Endocrinol 3:1053-1060

24. La Tour D, Mohan S, Linkhart TA, Baylink DJ, Strong DD 1990 Inhibitory insulin-like growth factor-binding protein: cloning, complete sequence, and physiological regulation. Mol Endocrinol 4:1806-1814

25. Garvey DJ, Longo LD 1978 Chronic low level maternal carbon monoxide exposure and fetal growth and development. Biol Reprod 19:8-14

26. Gilbert RD, Cummings LA, Juchau MR. Longo LD 1979 Placental diffusing capacity and fetal development in exercising or hypoxic guinea pigs. J Appl Physiol 46:828-834

27. Price WA Stiles AD, Moats-Staats BM, D'Ercole AJ 1992 Gene expression of insulin-like growth factors (IGFs), type 1 IGF receptor, and IGF-binding proteins in dexamethasone-induced fetal growth retardation. Endocrinology 130:1424-1432

28. Jensen A, Berger R 1991 Fetal circulatory response to oxygen lack. J Dev Physiol 16:181-207

29. Jost A Fetal hormones and fetal growth 1979 In: Keller P (ed) Gynecologic and Obstetric Investigation, Vol 5. Karger, Basel, pp 1-20

30. Mayhew TM, Jackson MR, Haas JD 1990 Oxygen diffusive conductances of human placentae from term pregnancies at low and high altitudes. Placenta $11: 493-503$
31. Westgren M, Selbing A, Stangenberg M 1989 Fetal growth and fetal glucose and $C$-peptide levels in relation to the degree of anemia in fetuses affected by rhesus isoimmunization. Acta Obstet Gynecol Scand 68:309-311

32. Lund PK, Moats-Staats BM, Hynes MA, Simmons JG, Jansen M, D’Ercole AJ, VanWyk JJ 1986 Somatomedin-C/insulin-like growth factor-I and insulinlike growth factor-II mRNAs in rat fetal and adult tissues. J Biol Chem 261: 10025-1(0)28

33. De 'Chiari TM, Efstratiadis A. Robertson EJ 1990 A growth deficiency phe notype in heterozygous mice carrying an insulin-like growth factor II gene disrupted by targeting. Nature $345: 78$

34. Han VKM, Hill DJ 1992 The involvement of insulin-like growth factors in embryonic and fetal development. In: Schofield PN (ed) The Insulin-Like Growth Factors. Structure and Biological Function. Oxford University Press, New York, pp 179-220

35. Moses AC, Nissley SP, Short PA, Rechler MM, White RM, Knight AB, Higg OZ 1980 Increased levels of multiplication-stimulating activity, an insulin-like growth factor in fetal rat serum. Proc Natl Acad Sci USA 77:3649-3653

36. Ooj GT. Orlowski CC. Brown AL. Becker RE. Unterman TG, Rechler MM 1990 Different tissue distribution and hormonal regulation of messenger RNAs encoding rat insulin-like growth factor binding proteins-1 and -2. Mol Endocrinol 4:321-328

37. Giudice LC, de Zegher F, Dsupin BA, de las Fuentas L. Crystal RA, Gargosky SM, Rosenfeld RG, Hintz RL Insulin-like growth factor binding proteins in the human fetus and neonate. Program of the 2nd International Workshop on Insulin-Like Growth Factor Binding Proteins. Opio, France, 1992, p 102

38. Wang HS, Chard T 1991 The role of insulin-like growth factor-I and insulinlike growth factor-binding protein- 1 in the control of human fetal growth. Endocrinol 1.32:11-19

39. Lasarre C, Hardouin S, Daffos F, Forestier F, Frankenne F, Binoux M 199 Serum insulin-like growth factor binding proteins in the human fetus. Relationships with growth in normal subjects and in subjects with intrauterine growth retardation. Pediatr Res 29:219-225

40. Brismar K, Gutniak M, Povoa G, Werner S, Hall K 1988 Insulin regulates the $35 \mathrm{kDA}$ IGF binding protein in patients with diabetes mellitus. J Endocrinol Invest 11:599_602

41. Holly JMP, Biddlecombe RA, Dunger DB, Edge JA, Amiel SA, Howell R, Chard T, Rees LH, Wass JAH 1988 Circadian variation of GH-independent IGF-binding protein in diabetes mellitus and its relationship to insulin. A new role for insulin? Clin Endocrinol 29:667-675

42. Suikkari A-M, Koivisto VA, Koistinen R, Seppala M, Yki-Jarvinen H 1989 Dose-response characteristics for suppression of low molecular weigh plasma insulin-like growth factor-binding protein by insulin. J Clin Endocrinol Metah 68:135-140

43. Boni-Schnetzler M, Schmid C. Mary J-L, Zimmerli B, Meier PJ, Zapf J, Schwander J, Froesch ER 199() Insulin regulates the expression of the insulinlike growth factor binding protein 2 mRNA in rat hepatocytes. Mol Endocrinol 4:1320-1326

44. Donovan SM, Oh Y, Pham H, Rosenfeld RG 1989 Ontogeny of serum insulin-like growth factor binding proteins in the rat. Endocrinology 125:26212627 